\title{
AN ANALYSIS ON STUDENT'S ERROR OF PASSIVE VOICE IN THE SIMPLE PRESENT
}

\author{
Dede Irawan \\ Prodi Pendidikan Bahasa Inggris, Universitas Wiralodra, Jl. Ir. H. Juanda KM.03, Indramayu 45213, \\ Indonesia, Dedeirawan.unwir@ac.id
}

Diterima 15 Juni 2019, disetujui 10 September 2019, diterbitkan 31 Oktober 2019

Pengutipan: Irawan, D.(2019). An Analysis on Student's Error of Passive Voice in the Simple Present. Gema Wiralodra, Vol 10, No 2, Hal 200-208, Oktober 2019

\begin{abstract}
This research is aimed to analyze and to know an error of the passive voice in the simple present, passive is needed in daily speaking and writing activity. In this research, the writers use a qualitative method and took 25 students as a sample of this research. While the result of this research, among others: 1 . there are 5 students who error on the use of verb, the students are looked confused to choose between Verb 2 and Also Verb 3 (Past Participle), the student cannot distinguish between irregular verb, regular verb and Verb 3 (Past Participle), 2. 4 students' error on the use to be they can distinguish to be in the passive voice with the use to be in past tense, 3. 6 students' error in the use to be and verb on passive voice of simple present.
\end{abstract}

Keyword: Error Analysis, Passive Voice, Present tense

\section{ABSTRAK}

Penelitian ini bertujuan untuk menganalisis dan mengetahui kesalahan passive voice pada simple present, passive voice sangat dibutuhkan dalam kegiatan berbicara dan menulis sehari-hari. Dalam penelitian ini penulis menggunakan metode kualitatif dan mengambil 25 siswa sebagai sampel penelitian. Adapun Hasil penelitian ini antara lain: 1. ada 5 siswa yang melakukan kesalahan dalam penggunaan kata kerja, siswa terlihat bingung untuk memilih antara kata kerja 2 dan kata kerja 3 (Past Participle), siswa tidak dapat membedakan antara kata kerja tidak teratur, kata kerja reguler dan Kata kerja 3 (Past Participle), 2. Ada 4 siswa yang melakukan kesalahan dalam menggunakan to be, para siswa tidak dapat membedakan to be passive voice dan past tense 3. Ada 6 siswa yang salah dalam penggunaan menjadi dan kata kerja pada passive voice.

Keyword: Error Analysis, Passive Voice, Present tense

\section{INTRODUCTION}

Grammar is one of skill in English that important which should be understood because it has influenced our writing ability, the mastery of grammar also can help the student to understand the rule to make sentences, whereas in English there are sixteen tenses. Michael Swan (2005) in the Practical English Usage, states that grammar is the rules that show how words are combined, arranged or changed to show certain kinds of meaning, the matter also is explained by Barbara Dykes (2007: 5) in the book of Grammar 
for Everyone state that "grammar is a language to talk about language" Depend on the definition, we can conclude grammar is important in the language learning's, because Grammar is the study of how a language works to communicate or also as a set of rules to shape language so that it has meaning or can be understood, but in the teaching and learning English, grammar still become a problem for students, it caused too many formulations of tenses is realized, so that it can hamper the understanding and ability of English language to students, whereas explained above that grammar is a unity that cannot be separated in learning English. One of the grammar learning that is difficult to understand is passive voice, in this study the student still confuse to changes Verb and to use to be, As we Know Passive voice is one of unit in grammar that is teaching in the school until university, Passive voice is a form of sentence in which the subject of the sentence receives action, not taking action. Unlike active voice that focuses on the party doing the action (doer of the action), this form is more focused on the party or object that receives the result of an action (receiver of the action). Hornby (2000:964) says that passive voice is the form of a verb that is used when the subject is affected by the action of the verb, while Azar (1989:120) says that in the passive, the object of an active verb becomes the subject of the passive verb. She adds that only transitive verbs (a verb that is followed by an object) that are used in the passive. Passive is needed in daily speaking and writing activity, the explanation of the expert of passive voice shows that passive voice very important to mastery of the students to can improve English skill especially in writing. AS we know English lessons have been taught since elementary school, but understanding in English has not been comprehensively mastered, for example, the mastery of Passive Voice that so far there are still many students who have difficulties, even found the use of passive voice structural patterns equated with past tense, besides that, the other error in passive voice of students, such as the use of vocabulary, to be, tenses and also changes subject to be object. This problem will be analyzed by the writer as an effort to develop and to know the difficulty factor's in making passive voice. 
The research that is related to analyzing of error students in passive voice has done by some researchers, as an example : an analysis of the second-year students' ability in writing passive voice at sma Negeri 1 sitiung that is researched by Herda Dewi Ningrum and Lisa Tavriyanti who analyzed the correlation between writing ability and the error of student in passive voice, this research has focused error analysis in some tenses, such as : the simple present tense, sentences for the simple past tense, and sentences for simple future tense, whereas each tense has taken 10 tenses to be analyzed, As for other studies about passive voice is an error analysis on the use of passive voice in writing report text by eleventh grade students of sman 1 nganjuk, this research explained about the errors of using passive voice in report text and also To describe the causes of errors in writing report text made by students, although these research focus on error analysis in passive voice it has to need to develop in order to find out the factor of error in passive voice. Depend on the research the writer will analyze an error passive voice of students in the simple past tense, this research is aimed to know the factor error's and the types of error in a passive voice more specifically in the simple present tense, in this research, also is expected to know correlation the mastery of simple present with passive voice. According to Krohn (1971) states that Simple present tense is tense denoting an action happening in this time" The use of simple present tense often makes students confused with its complexity, in the teaching and learning process the students still difficult to understand simple present tense, so that this research also can analyze the mastery of simple present tense and passive voice in the students. While error analysis is a branch of applied linguistics. It is concerned with the compilation, study, and analysis of errors made by second language learners and aims at investigating aspects of second language acquisition. Nourish in Chotimah (2013) states that about distinguishes between different types of anomalous language behavior, the error, the mistake, and the lapse.

1. An error is a systematic deviation when a learner has not learned something and consequently gets it wrong.

2. A mistake is an inconsistent deviation when the learner sometimes get it right

3. but sometimes he makes a mistake and 
Depend on the explanation above, the writer will control this research is focusing on Error Analysis of Passive Voice in the simple present tense, and it is expected Theoretically, this research can give contribute to the grammar scientific knowledge especially in the passive voice and also develop students capacities in English.

\section{METHOD}

The writer uses qualitative method by using qualitative descriptive design in the research, Descriptive research is used to identify and classify the elements or characteristics of the subject and describe the subject or to get information about the current condition of certain object, Aruknto states the descriptive research is not aimed at testing a certain hypothesis, but only describes the phenomenon, situation, and condition that happen during the research. It is excepted can analyze the factor error in the passive voice in the simple present of students deeply, this research will be recommended the strategy in teaching passive voice that can be accepted by the students. This research will take 20 students of the First semester in AMIK Purna Niaga Indramayu as the sample, and in the process to collect the data the writer uses the question as instrument, there are five questions will be answered by the students, whereas the students must do the questions and changes form active voice in present tense to be passive voice and then the writer will analyze the instrument to get the data that of the error passive voice in simple present of students. This qualitative research is expected to help researchers find out the mistakes of students in making passive voice and the factors that cause these errors, but also by using the method, researchers can find out the weaknesses of students in understanding passive voice, Such As the mastery of English grammar, teaching method and the other factors.

\section{RESULT AND DISCUSSION}

Hornby (2000:964) says that passive voice is the form of a verb that is used when the subject is affected by the action of verb, the mastery of passive voice in the students still to be a problem in the teaching English, it caused the students to confuse to distinguish between passive voice, past tense and also past perfect that is considered have similarity in the use of 
formulation especially in verb and to be, so these problems that influence the writer to analyze an error passive voice of student. Although there is many researches of an error analyze of passive voice such as : an analysis of the second-year students' ability in writing passive voice at sma negeri 1 sitiung that is researched by Herda Dewi Ningrum and Lisa Tavriyanti who analyzed the correlation between writing ability and the error of student in passive voice and As for other studies about passive voice is an error analysis on the use of passive voice in writing report text by eleventh grade students of sman 1 nganjuk, this research explained about the errors of using passive voice in report text and also to describe the causes of errors in writing report text made by students, these researches is a reference to make analyze of passive voice more specific that is focus on an error analyze passive voice in simple present of student. As an effort to develop the research, the writer took 20 students in Amik Purnama Niaga Indramayu, where previously the students worked five questions in the instrument, the questions are worked by students is changes active form to be a passive voice in the present tense, although these questions are:

The instruments an errors analysis of passive voice in simple present tense

\begin{tabular}{ll}
\hline Number & Questions in the instruments \\
\hline 1 & The Boy Cooks Fried Rice every morning \\
2 & Rudi Buys a red shirt every chines New Year \\
3 & They work English Assignments on the campus every Friday \\
4 & The headmaster checks the teacher in the school every Monday \\
5 & He Sells the shoes in the traditional market every Sunday \\
\hline
\end{tabular}

Depend on collecting the data and analyze the instrument of 20 students, the writer found some errors on the passive voice in the simple present, as for the mistakes, among others: the use of verb, to be, the process change between subject to the object, the position of adverb of time and also the position adverb of place. The result of this research shows: From 20 students who become sample in this research, there are 15 Students who error in the passive voice in the simple present, the error is varieties, such as the use of verb, the use of to be and then error in the changes subject to be object in focus, to choose part of 
speech. In the analyze of instruments 5 Students error in the use of the verb, in this case, most of the students are looked confuse to choose between Verb 2 and Also Verb 3 (Past Participle), so the data can be seen in following of the sample.

The Errors use Verb in Passive voice of Simple present tense

\begin{tabular}{ll}
\hline Number & The answer to students in the instruments \\
\hline 1 & Fried Rice is Cooken by every morning \\
2 & A redshirt is Buyed by Rudi every chines New Year \\
3 & English Assignments is Working by them every Friday \\
4 & The teacher is check by the headmaster in the school every Monday \\
5 & The shoes is selled by he in the traditional market every Sunday \\
\hline
\end{tabular}

Base on the data, we can show the use and choose verb in the passive voice is most error who are worked by the students, the student cannot distinguish between irregular verb, regular verb and Verb 3 (Past Participle), the process of the changes the verb is the important basic in the passive voice, so when the students error use the verb the meaning of passive voice is wrong. While the other error passive voice in the simple present of the students is the use of to be, as for the data among others:

The sample of the data an error of use to be on the passive voice in the simple present

\begin{tabular}{cl}
\hline Number & The answer of students in the instruments \\
\hline 1 & The Fried Rice did Cooked by every morning \\
2 & A red shirt was Bought by Rudi every chines New Year \\
3 & English Assignments were Working by them every Friday \\
4 & The teacher dose checked by the headmaster in the school every \\
& Monday \\
5 & The shoes was selt by he in the traditional market every Sunday \\
\hline
\end{tabular}

The student who errors in the use to be of the passive voice in the simple present were 4 students, they can distinguish to be in the passive voice with the use to be in past 
tense, this problem is always found some researches of passive voice, the data show the mastery of formulation the tenses will influence the students capabilities in passive voice. In this research also, the writer found the other problem that is the error on the use of verb and to be, actually as we know this process is basic learning in grammar, but in the fact, the error still face in the student, so the data can show in the following of the sample:

The sample of error in the use of verb and to be on passive voice in simple present tense

\begin{tabular}{cl}
\hline Number & \multicolumn{1}{c}{ Answer of students in the instruments } \\
\hline 1 & The Fried Rice Cooks by the boys every morning \\
2 & A red shirt was Buy by rudi every chines New Year \\
3 & English Assignments was Works by them every Friday \\
4 & The teacher did checks by the headmaster in the school every Monday \\
5 & The shoes does selled by he in the traditional market every Sunday \\
\hline
\end{tabular}

The students who error in the use to be and verb on the passive voice of the simple present, there are 6 students, the problem is dominant that is found in this research because the students' lake to mastery a grammar comprehensively so that is influence error in the passive voice of the students.

\section{CONCLUSION}

Depend on the data that has collected in the students about an error analyze passive voice in simple present, it can show some problems the mastery of students in passive voice, form 20 students who are taken as sample, the writer found some errors, there are 15 students who make errors on passive voice of simple present tense, among others: 1. 5 students errors on the use of verb this case, most of the students are looked confused to choose between Verb 2 and Also Verb 3 (Past Participle), the student cannot distinguish between irregular verb, regular verb and Verb 3 (Past Participle), 2. 4 students error on the use to be they can distinguish to be in the passive voice with the use to be in past tense, this problem is always found some researches of passive voice, the data show the mastery of 
formulation the tenses will influence the student's capabilities in passive voice, 3 . There are 6 students, the problem is dominant that is found in this research because the students' lake to mastery a grammar comprehensively so that is influence error in the passive voice of the students.

\section{REFERENCES}

Algani, M. M, dkk. (2014). The Ability to Change Active sentence into passive sentence student Class X MA Gisiting. Jurnal Kata.

Adele, C. (2017). Phases and Calusa in the word of Polupinthesis in tolake language, Jurnal Education, Vol. 14, No. 2, Hal: 127 -140

Alvin, L.P. (2014). The Passive Voice in science communication. Vol. 13. No. 01, Hal: 115

Amdur, R.J. dkk. (2010). Use of the passive voice in medical. Amwa Journal, Vol. 25, No.3. 2010. Hal: 98-103

Azar, B.S. (1989). Understanding and Using English Grammar. America: Prentice Hall Regents,

Bahri, S \& Sugeng, B. (2009). Difficulties in Writing in Vocabulary and Grammar of the second year students of SMPN 1 Selong East Lombok West Nusa Tenggara in The School Year 2008/2009. http://journal.uny.ac.id/index.php/joe/article/download/197/98.

Cahyono, B.Y, dkk. (2016). Indonesia Students' Writing Proficency and Their Ability in Using Complex sentences. International Journal on studies in English language and literature (IJSELL), Vol 4, No 1, Hal 22-32

Dykes, B. (2007). Grammar for Everyone: Victoria: Acer Press

Fang, XIE \& Xue-mei, J. (2007). Error analysis and the EFL classroom teaching College of Foreign Languages. Education Review.

Hornby, A.S. (2000). Oxford Advanced Learner's Dictionary of Current English. London: Oxford University Press

Lodrup, H. (2014). Long Passive in Norwegian: Evidence for comolex Predicates. Nordic Journal of Linguistics, Vol 37, No 3, Hal 367-391. 
Kurniasih, H.C. (2013). An Analysis of Students' Errors on the Use of Passive Voice in Simple Past Tense. Department of English Education. State Islamic University Syarief Hidayatullah Jakarta.

Nurafifah. (2007). 'Teaching Passive voice to the Third Year Students of SMU Negeri 1 Maтuju', unpublished Thesis. Makassar: FBS UNM

Sukmawati, Y. (2018). Error Analysis in using Passive Voice. Journal of English Education and Development, Vol. 2 No. 1

Susanti, Asih. 2013. "Penggunaan Kalimat aktif dan Kalimat pasif dalam tulisan Siswa Kelas VII H SMP Negeri 2 Kertasura”. Naskah Publikasi. Juni 2013. Halaman 1-17. Surakarta: Universitas Muhamadiyah Surakarta. Diakses Pada 18 November 2019 (http://eprints.ums.ac.id/25167).

Sutana, DWI. (2009). Analisis Kalimat pada artikel besar pasak daripada tiang. Jurnal Widyaparwa, Vol. 37. No.2, Hal 185-200

Swan, M. (2005). Practical English Usage. Third edition. New York: Oxford University Press

Wexler, K \& Perovic, A. (2010). Development of Verbal Passive in Williams Syndrome. Journal of speech, Language, and Hearing Research, Vol. 53, Hal 1294-1306.

Yannuar, N. (2014). Active and Passive Voice Contructions by INondeinsian students Writers, Theory and Practice in language studies, Vol. 4, No. 7, Hal 1400-1408. 